\title{
Study on Practice Teaching System of Undergraduate Industrial Design in Comprehensive University
}

\author{
Shi Bai ${ }^{1,2, a}$, Qiang $\operatorname{Sun}^{1}$ \\ ${ }^{1}$ School of Art and Design, Bengbu University, 233000 Bengbu, Anhui, China \\ ${ }^{2}$ School of Arts, Southeast University, 210000 Nanjing, Jiangsu, China
}

\begin{abstract}
The Industrial Design of the comprehensive university should actively carry out education and teaching research and reform, where practice teaching plays an increasingly important role in Industrial Design education. Focusing on the training of high-quality professionals, the practice-based Industrial Design teaching system was discussed. The guiding ideology and the formulation of guidelines for establishing a practical teaching system, were proposed as well as a multiple-level innovation and open practice teaching system structure. At the same time, the important features of the practical teaching system of Industrial design are explained, such as proportion of time, teaching module, teaching platform, teaching arrangement, etc. which provide reference theory and method for the practical teaching of Industrial Design.
\end{abstract}

\section{Introduction}

With the needs of China's economic and social development, more and more colleges and universities have set up Industrial Design, including a large number of comprehensive and multiple-disciplinary universities. At present, a relatively large number of new Industrial Design talents have been initially formed. Industrial Design as a multiple-disciplinary application-oriented profession, requires comprehensive universities to take advantage of their own strengths and think about how to scientifically arrange relevant teaching systems, to harmonize and rationalize theoretical teaching and practical teaching of courses, and to cultivate talents with design and practical ability and innovative practical ability.

\section{Industrial design teaching system}

Industrial design aims to guide innovation, promote business success, and provide a better quality of life. It is a design activity that applies a strategic problem-solving process to products, systems, services, and experiences. It is an interdisciplinary profession that closely connects innovation, technology, commerce, research, and consumers, conducts creative activities together, visualizes the problems that need to be solved, proposes solutions, and reconstructs problems. As an opportunity to build better products, systems, services, experiences or business networks, it provides new value and competitive advantage[1]. In recent years, the State Council has successively issued important documents and plans such as Industrial Transformation and Upgrading Planning 2011-2015, Several Opinions on Promoting the Integration and Development of Cultural and Design Services and Related Industries and Made in China 2025. In the Industrial design industry, Industrial Design plays a very important role in the development of innovative countries and high-quality economic development. Therefore, the entire design industry urgently needs a large number of highly qualified professionals.

\subsection{The goal of talent cultivation}

Industrial design has comprehensive, cross-cutting, and systematic disciplinary characteristics. It involves a wide range of content and fields. This requires that universitytrained professionals must have a relatively broad knowledge system and a relatively comprehensive practical ability[2]. At present, the industry generally believes that excellent Industrial designers should have the ability to solve problems creatively. Simply put, it is to analyze who you are designing for, what you are designing, why do you design this way, and how your design can solve this problem. Specifically speaking, it is necessary to have the ability to complement logical thinking and visual thinking, good design performance, good model-making ability, data collection and processing ability, good computer-aided design ability, good communication and expression ability, design activity management ability, and the ability to be familiar the product from design and manufacturing to marketing.

\subsection{Cultivation emphasis of innovation talent}

From a design perspective, innovation starts with problems and comes from practice. Practical teaching emphasizes the individual of students more than

\footnotetext{
* Corresponding author: ${ }^{\mathrm{a}}$ artbaishi@163.com
} 
theoretical teaching. Emphasis on practical teaching helps students to fully understand and master theoretical knowledge, and urges students to develop theory and practical style and rigorous and serious work attitude. At the same time, it improves hands-on operational ability and professional competitiveness gradually. In the process of training, students should be guided to actively construct the knowledge system of the subject, in order to cultivate students' exploration spirit, innovation consciousness, and comprehensive quality to generate the combined effects of knowledge, emotion, intention, and energy, so as to help students obtain innovative design results and obtain their own comprehensive development. Industrial design as a comprehensive, cross-cutting, and systematic edge discipline, whose essence is innovation, must enable students to build a sound professional knowledge and skills and reserve the knowledge structure and literacy that can adapt to social development by strengthening the practical teaching process in the limited time of on-campus learning. Making practicality plays a huge role in the training of design talents' comprehensive capabilities is also one of the important features of modern industrial design education in the world.

\section{Establish a practical teaching system for innovative applications}

\subsection{Guiding principles and guidelines}

The teaching model of Industrial design practice in integrated universities is different from that of art schools. It is difficult to adopt a mature design studio system. The formulation of the entire practical teaching system must be based on the orientation of personnel training and personnel training programs in the school. In order to establish a practical teaching system that meets the needs of Industrial design professionals in the school's general education requirements, there must be clear principles and guidelines.

(1) Conduct systematic organic teaching of all aspects of practice teaching, adhere to the tandem nature of the practice teaching system, and establish a goal system for talent practice ability training.

(2) Make full use of the school's shared resources and elements, make effective use of the practice centers and laboratories inside and outside schools, and strive to create interdisciplinary and integrated collaborative teaching conditions so that organic quality education and professional skills training are organically combined.

(3) The practical teaching system should highlight certain professional features. The teaching content and module structure should clearly reflect the complete knowledge chain and skill sequence of the Industrial design profession

(4) Adhere to the open teaching thinking, adopt corresponding practical teaching modes and means for different practical teaching links, and focus on the optimization of teaching effects.

\subsection{Reasonable practice teaching architecture}

Establish the goal of fostering applied Industrial design talents with "thick foundation, strong ability, high compounding, and heavy features", scientifically adjust the proportion of theoretical teaching and practical teaching, reform the original curriculum experimental design, and set up a link to increase innovation and entrepreneurship practice teaching. Finally, an open Industrial design practice teaching architecture is established with multiple-level innovation and application based on design performance and skill operation, based on design thinking and design and practical ability, and supported by design research and off-campus practice.

\section{Important features of industrial design practice teaching system}

\subsection{Improve the proportion of class hours in practical teaching}

Practical teaching and theoretical teaching are both important links in the teaching system. Both are complementary and have equal status. In view of the characteristics of the discipline of Industrial design, it is necessary to begin by formulating and revising the training plan for talents, and to make full use of the existing teaching conditions to establish a scientific and rational curriculum system and a practical teaching system that conforms to the development law of professionals. The content of theoretical teaching and practical teaching should be optimized and integrated, and efforts should be made to harmonize and coordinate system design, to communicate with each other, to be relatively independent, and to gradually improve. In order to cultivate students' comprehensive professional knowledge and skills and their ability to innovate and start-up, the specific requirements of each teaching session are refined. Inviting peer experts to fully demonstrate and improve the proportion of hours of practical teaching, so that the ratio of theoretical teaching and practical teaching of the professional 6:4. The common time ratio of comprehensive universities should be broken to make the practice teaching system safe.

\subsection{Multiple-level progressive practice teaching module}

The innovative application of Industrial design practice teaching system adopts multiple-level progressive practice teaching modules, which are divided into four levels: general basic knowledge practice, professional foundation practice, professional comprehensive practice, and innovative design practice. Among them, based on the design performance and skill operation, the main line of various product design topics, relying on design training, design research, and extracurricular activities as an aid to the orderly implementation of various aspects of practical teaching. 
(1) The level of general basic knowledge is set for junior students, focusing on students' acceptance of systematic design concepts, providing academic background and basic skills for follow-up related courses, inspiring students' interest of study and desires to explore in Industrial Design. Practical teaching at this stage is mainly performed in the computer room, professional laboratory, design practice center, and off-campus practice base of the school. Practice teaching links and methods are mainly cognitive practice, materials practice, metalworking practice, sketching practice, professional basic courses and experiments.

(2) The level of professional foundation practice is set for students of grades 2-3. Through the practical training of professional basic courses in this subject, students can master the normative design flow, good design habits, scientific design methods, reasonable design experience, and develop good hands-on skills and innovation. Practical teaching at this stage is mainly conducted in professional laboratories, design practice centers, and off-campus practice bases. Practice teaching links and methods are mainly model-making, molding techniques, computer-aided design, practice of course exercises, professional investigations and professional internships.

(3) The level of professional comprehensive practice is set for students in grades 3-4 to train students to apply their own knowledge and skills to thematic design research and practice through the comprehensive practice of professional curriculum practice, design special research practice, graduation practice, graduation design, etc. , focusing on cultivating students' ability to find problems, analyze problems, and solve problems. Practical teaching at this stage is mainly conducted in professional laboratories, design practice centers, and off-campus practice bases or enterprises.

(4) The level of innovation design practice mainly refers to the expansion of the practice beyond the prescribed teaching plan, including discipline competitions, professional design competitions, innovative entrepreneurship training programs for university students, and production, research and development projects[3]. This type of practical activity has rich levels, diverse forms, and high flexibility. It can give full play to the students' autonomy and enterprising spirit, and ultimately train professionals with innovative ideas and abilities.

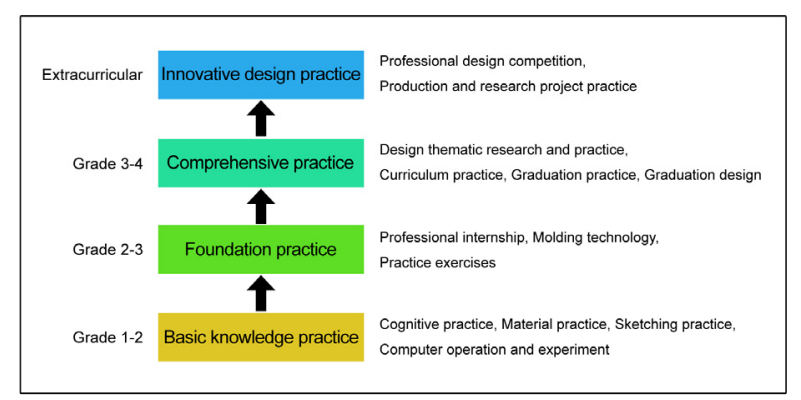

Figure 1. Practice teaching system of industrial design

\subsection{Internal and external combined innovative practice teaching platform}

The Industrial design practice teaching system needs to be implemented through two kinds of teaching platforms: on-campus and off-campus. The on-campus teaching platform includes a studio, a computer training center, a model production room, a professional laboratory, a design practice center, etc. It mainly conducts various types of professional skills training, curriculum experimental training, computer aided design training, material processing technology training, metalworking practice, design research and other practical courses outside the teaching plan and independent practice links. The off-campus teaching platform includes an offcampus practice base, practical training bases for schoolindustry cooperation, and a production-learning-research cooperation practice center. It mainly carries out teaching and research activities such as production and research projects, professional investigations, professional internships, graduation practice, and graduation design. In recent years, most universities in China are actively exploring and attempting to establish a practical teaching base with different functions outside the school. Through cooperation with related companies, we have gradually created a professional practice model of "real issues, true design, and real environment"[4]. This will greatly promote the training of professionals.

The off-campus teaching platform is an effective supplement to the practical teaching system. Through out-of-school practice training, students learn about society and enterprises, are familiar with the implementation process of design projects, enhance professional knowledge and skills, and establish a spirit of communication and cooperation. Of course, we must note that although the practice outside the school is an important part of talent cultivation, the university itself needs to continue to evolve. Because university education undertakes the important task of research and innovation, it is necessary to establish students' forwardlooking awareness, innovative spirit, and exploration skills in personnel training. Therefore, courses on "Designing Special Topics in Research and Practice" should be set up in the practical teaching in schools. Design teachers and corporate designers from wellknown colleges and universities should hold short-term "Workshops" so that students can continuously learn rich design concepts, design methods, humanities and literacy, strive to achieve energy and energy, both strong practical ability, but also a strong ability to design thinking and development potential.

\subsection{Combination of work and study practice teaching arrangements}

Reference is made to the combination of learning and teaching patterns that have been used by foreign tertiary institutions for learning semesters and work semesters alternately, and to give full play to the two different teaching platform resources inside and outside the school. On the one hand, the classroom teaching in the school education must be closely followed. On the other hand, the internship work should also be taken into consideration. The two should be organically 
combined[5]. It is better to arrange two internships during the undergraduate years. The first summer vacation between the second and third grades can be arranged at the internship practice base, learning by "problem-oriented". After studying certain professional courses, students are promptly involved in the production, study and research projects and corporate design projects so that students can test their abilities in practice and discover shortages. Afterwards, they will start targeted learning with questions, which can effectively improve students' initiative and interest in learning. They can also help students to further understand what they have studied and what they will do in the future so that they can make reasonable plans for their career development as soon as possible.

Another internship is scheduled for the fourth grade winter vacation. Students choose suitable internship units for a three-month graduation internship with the help of tutors according to their professional aspirations and professional expertise. Students have completed the study of the professional courses before this time. Through the participation of the "quasi-professional designer" in the work of the company, students can receive comprehensive training to improve their ability and attainment from all angles.

\section{Practical teaching needs support of hardware and software}

The development of Industrial Design practice teaching requires a complete teaching system structure and perfect software and hardware support. The hardware mainly refers to the campus computer room, professional laboratory, design practice center, design workshop and off-campus internship practice base. The software mainly refers to the practical teaching staff, practice teaching mode, practical teaching content, practical teaching security system, and evaluation mechanism. When the level of software and hardware construction matches the structure of the practical teaching system, the effectiveness of practical teaching can be maximized. In recent years, many colleges and universities have achieved certain results in practical teaching software and hardware construction, such as the establishment of computer-aided design laboratories, product processing technology laboratories, interaction design laboratories, three-dimensional printing laboratories, design practice centers, design and research centers, etc. In addition, a school-enterprise cooperation practice base and a production-learning-research project cooperation base have also been established outside the school; Many colleges and universities also employ "dual-energy" teachers, select professional teachers to participate in corporate training, formulate curriculum syllabus, curriculum design practices, professional practice management methods, graduation design specifications, and assessment standards.

Through the analysis of the exploration and implementation of Industrial design practice teaching, hardware is the necessary foundation and the precondition for all practical teaching activities. The software plays a key role in the level of practical teaching, the quality of practical teaching and the effect of practical teaching. In the meanwhile, the degree of emphasis on practical teaching and the allocation of teaching funds by school management departments are also indispensable factors that affect the construction of practical teaching systems.

\section{Acknowledgment}

Funding: Supported by Social Science Key Project of Bengbu University (No.2017SK04zd), Experimental Teaching and Experimental Technology Research Project of Bengbu University (No. 2016syxm17), Quality Engineering Project of Bengbu University (No. 2016JYXM25).

\section{References}

1. Guo.H.J,Wang.H.B, On the Difficulty and Strategy of Improving the Employment Competitiveness of Industrial Design Graduates, Design Research, 04(2017); 20-25

2. Xu.J,The Study of Product Design"Progressive Project-Based Learning'Teaching Model,(Doctor Thesis) Jiangnan University, Wuxi, Jiangsu, China, 2017

3. Xi.X.Y,Meng.L.L, Research on the Training Mode of College Students' Innovation and Entrepreneurship Based on Discipline Competition, Modern Vocational Education, 28(2017); 60-62

4. Hou.Y,Analysis of Purpose and Content in Practice Education of Universities Industrial Design, Design, 02(2015); 142-143

5. Fan.X.X,Work Integrated Learning Mode in Austral ia and Its Enlightenment, Journal of Teacher Education, 03(2017); 102-108 